\title{
TUROPEAN REGIONAL INTEGRATION 4 IN THE DRAFTING OF THE EASTERN PACT IN 1934-1935: INTERESTS OF THE BALTIC ENTENTE AND THE LITTLE ENTENTE
}

\section{Dalia Bukelevičiūtè}

Vilnius University, E-Mail: Dalia.Bukeleviciute@if.vu.lt

\section{Acknowledgments}

This paper has been presented at the Fourth international conference on Baltic and Nordic Studies in Romania Empire-building and Region-building in the Baltic, North and Black sea areas hosted by the Romanian Association for Baltic and Nordic Studies and Ovidius University of Constanta, May 24-26, 2013.

\begin{abstract}
:
This article follows the interests and actions of the countries of Baltic and Little ententes with regard to the projected Eastern Pact, which raised marked interest in East-Central Europe in 1934-1935. It seeks to give an answer to the question whether the negotiations over the Eastern Pact brought the interests of the Baltic states closer to those of the Little Entente. It highlights that the progress of negotiations made it clear that each country was more concerned with its security than the common security of the entire bloc, even though both the Little Entente and the Baltic Entente were established for the sake of safeguarding security of their member states and harmonising their foreign policy in this respect. Both regional security bodies declared their agreement to the Eastern Pact but the key difference was that the Baltic Entente was expected to participate in the Eastern Pact directly, whereas only Czechoslovakia was singled out from among the members of the Little Entente. The analysis concludes that Lithuania and Czechoslovakia were the two countries which were most actively concerned with the conclusion of the Eastern Pact.
\end{abstract}

\section{Rezumat:}

Articolul urmărește interesele și acțiunile țărilor membre ale Antantei Baltice și ale Micii Antante cu privire la proiectul Pactului Oriental, proiect care s-a bucurat de un mare interes în Europa Central-Răsăriteană în anii 1934-1935. Acesta caută să dea răspuns întrebării dacă negocierile cu privire la Pactul Oriental au apropiat interesele statelor baltice de cele ale statelor Micii Antante. Este subliniat faptul că 
desfăşurarea negocierilor a vădit faptul că fiecare dintre țări era mai interesată de securitatea sa decât de aceea comună a întregului bloc, deși atât Mica Antantă cât și Antanta Baltică fuseseră concepute pentru salfgardarea securității statelor membre și armonizarea politicii lor externe în acest scop. Ambele structuri de securitate regională și-au declarat acordul față de Pactul Oriental, cu diferența fundamentală că Antanta Baltică era de așteptat să participe direct la Pactul Oriental, în vreme ce dintre membrii Micii Înțelegeri doar Cehoslovacia urma să facă acest lucru. Analiza de față conchide că Lituania și Cehoslovacia au fost cele două state cele mai interesate de finalizarea cu succes a negocierilor pentru semnarea Pactului Oriental.

Keywords: Oriental Pact; Little Entente; Baltic Entente; Czechoslovakia; Lithuania; regional security; collective security

In 1934-1935, the idea of the Eastern Pact forced European states to revise and re-evaluate the possibilities for regional cooperation. In fact, the main idea behind regional cooperation was to safeguard the security of individual states and the security of Europe or, in other words, to maintain peace in Europe. The issues of peace in Europe and security of European states were prompted by the arising tensions in countries' bilateral relations, the division of countries into revisionists and anti-revisionists, the changing balance of powers, i.e. the growing German role and the declining French influence. From 1933 (especially after the withdrawal of Germany) the power of the League of Nations, which was initially founded as a guarantor of peace and stability in Europe, began to decline. Trying not to lose its influence and balancing in the international policy, France started seeking closer relations with the USSR, which was also striving to strengthen its positions. The great powers decided to admit the Soviet Union to the League of Nations as a fullfledged member. Therefore, the mutual relations between France and the USSR, the balancing of Great Britain and an open German and Polish opposition determined the evolution of international relations in 1934-1935.

The circumstances of negotiations over the conclusion of the Eastern Pact have received extensive coverage in historiography. Historians from various countries focus on revealing the interests of individual countries and personalities under these circumstances. In the attempt to reveal the interests of the Little Entente and the Baltic Entente in pursuance of regional cooperation in Europe, the article mostly relies on Lithuanian and Czech archival material; the pro-memorias and diplomatic correspondence of the Lithuanian foreign minister Stasys Lozoraitis are an especially valuable source of important information. Lithuanian historians Z. Butkus and V. 
Žalys, Estonian historian Magnus Ilmjärv, Czech historian Zdeněk Sladek devoted considerable attention to these problems in their works. The tendencies of regional cooperation have been thoroughly addressed by Slovak historian Valerián Bystricky.

The first more serious contacts between France and the USSR were established at the end of 1933 and intensified especially from February 1934, when J.L. Barthou became the French foreign minister. From April the diplomatic discussion launched by the French Foreign Ministry began, which had to lay foundations to "a rather complicated project entitled the Eastern Pact". ${ }^{1}$ By its initial versions, the Eastern Pact had to be concluded on the basis of a regional pact of mutual assistance, a French-Soviet guarantee pact and a general pact of all the signatories. ${ }^{2}$ Though the system established for safeguarding security may seem rather cumbersome and hardly enforceable, V. Bystricky, one of the most prominent researchers in this field, highlighted that with the system of collective security, the international relations were supplemented with an absolutely new form of security organization based on regional pacts among the great powers and the small powers. ${ }^{3}$ Hence, Europe got involved in long-lasting discussions over the safeguarding of security in an absolutely new form, which had not yet been tested and checked in international relations.

According to the initial idea of the Eastern Pact, France, the USSR, Czechoslovakia, Poland, Germany, Lithuania, Latvia, Estonia and Finland were projected as parties to the pact. Most importantly, the parties to the pact did not only have to agree among themselves but also to agree on the general idea of maintenance of security. To bring regional integration to life, bilateral and multilateral relations among the states intertwined among themselves. The greatest concern was Germany's revisionist tendencies and its attempts to revise the Versailles system. Tensions were also fuelled by the PolishGerman non-aggression treaty signed in 1934 and the changes in the Polish foreign policy. On the other hand, not all countries had crystallised their relations in respect of the USSR until that time. The strengthening role of the USSR as one of the initiators was not only an unpopular but also alarming sign among some countries; yet some countries cardinally changed their positions expressed in 1934 in favour of the USSR.

According to historian Bystricky, collective security emerged and developed as a reaction to all the negative events in the international

\footnotetext{
1 Stanisław Żerko, Niemiecka polityka zagraniczna 1933-1939 (Poznań, 2005), 125.

2 Zdeněk Sládek, Malá dohoda 1919-1938 (Praha, 2000), 126

3 Valerián Bystrický, Kolektívna bezpečnost́ anebo neutralita: balkánske štáty a vytváranie záruk bezpečnosti v 30. rokoch (Bratislava, 1981), 139.
} 
situation. ${ }^{4}$ In the Soviet understanding, the Eastern Pact had to bring together all the countries threatened by the German expansion. Hence, Germany was destined to become the central figure in the negotiations. Germany's position was quite the opposite to what the initiators of the Eastern Pact could expect; its diplomacy tried to pave the way for aggression, to seek for allies, to destroy the collective security system, the French security system, to conceal its aggressive plans, etc. ${ }^{5}$ According to the initial idea of the Eastern Pact, it should involve Germany's neighbours. The USSR and France brought their proposals for the participation of individual countries in the Eastern Pact in June 1934. It fuelled an intense discussion on the safeguarding of security, regional integration, and mutual interests.

Germany and Poland were least concerned with concealing their hesitation, doubts or even critical disposition. Finland was the first to refuse participation in the pact. The Finnish foreign minister Antti Hackzell informed Neurath on his visit in Berlin on 9 June that his government would not contribute to the pact. Finland was afraid that the USSR was merely looking for an excuse to deploy its military troops in Finland. ${ }^{6}$ In the meantime, Lithuania and Czechoslovakia, fearing for their potential political isolation and military threats from Germany, were most in favour of the proposal. Czechoslovakia was the first to express its agreement to participate in the Eastern Pact on 2 July, abstaining from any specific reservations. The USSR and France were prone to single out Czechoslovakia from among the members of the Little Entente. The other two member states - Romania and Yugoslavia - were not invited to contribute to the collective security system. Romania demonstrated a certain interest in regional integration. However, according to historian Bystricky, the USSR was rather reserved regarding the Romanian interests to adhere to the Eastern Pact as it was prone to believe that only the countries of the region should accede to the pact. 7 The Soviets were convinced that the Romanian accession could be rather troublesome. It was Józef Beck who spoke for the inclusion of Romania in the Eastern Pact in the beginning of June by simultaneously speaking for the exclusion of Lithuania and Czechoslovakia. ${ }^{8}$ Such Polish interests were sceptically evaluated by Czechoslovakian diplomats fearing that closer relations between Poland and Romania could be a threat to the entire Little Entente. Prague received a message from Warsaw: "It is obvious that ever since the

\footnotetext{
4 Ibid., 139

${ }^{5}$ Ibid., 120

6 Żerko, 127.

7 Bystrický, 145

8 Piotr Wandycz, The twilight of France Eastern Alliances 1926-1936 (Princeton, New Jersey, 1988), 363

42
} 
Polish Foreign Ministry got involved in the conflict with us, it has conspicuously and in every step demonstrated its alliance with Romania and amicable relations with Yugoslavia. It aims to weaken the Little Entente as a unit and to isolate Czechoslovakia". ${ }^{9}$

Even before active negotiations over the Eastern Pact began, the member states of the Little Entente essentially changed their policy in respect of the USSR. The meeting of the Permanent Council of the Little Entente held on 22 January 1934 in Belgrade agreed that it was a favourable moment for normalising the relations with the Soviets. ${ }^{10}$ The Czechoslovakian foreign minister Edvard Beneš saw the alliance with the USSR in the framework of the Eastern Pact as one of the key objectives in the existing situation. ${ }^{11}$ The most strenuous negotiations were expected to take place between the USSR and Romania regarding the controversy over Bessarabia but the countries succeeded in reaching an agreement and Czechoslovakia and Romania established diplomatic relations with the USSR on 9 June 1934.

Yugoslavia did not only refuse to establish relations with the USSR but pursued closer relations with Nazi Germany. Pressed by the international situation and the great powers, Yugoslavia expressed its formal agreement. It did not itself consider any possibilities of joining the Eastern Pact as it was not willing to participate in the regional pact, with the USSR taking part in its drafting. ${ }^{12}$ Thus, according to historian Sladek, "the unity of the Little Entente was in the midst of its first open political crisis manifesting itself by the diverging positions in respect of the Eastern Pact, in particular as regards the normalization of relations with the USSR" ${ }^{13}$ In fact, the conference of the Permanent Council of the Little Entente held on 18-20 June 1934 in Bucharest approved the idea of the Eastern Pact as the pact aiming at the safeguarding of security in Eastern Europe.

On 14 June the USSR made a proposal to the Baltic states, when the three countries were already in the midst of intensive coordination of their actions regarding the establishment of the Baltic Entente. The establishment of the Baltic Entente was often compared to the Little Entente. Czechoslovakian diplomats in Kaunas were exceptionally active and followed both the establishment of the Baltic Entente and the possibilities of countries' participation in the Eastern Pact. Before the first meeting of the

\footnotetext{
${ }_{9}$ Czechoslovakia envoy extraordinary and minister plenipotentiary in Warsaw report of 10.05.1934 from Warsaw to the Ministry of Foreign Affaires of Czechoslovakia, Archive of Ministry of Foreign Affaires of Czech Republic (hereafter, AMZV).Pz-Varšava. 1934. č.j.5017. 10 Sládek, 126

11 Ibid.

12 Bystrický, 149

13 Sládek, 127
} 
representatives of the Baltic states on 7 July in Kaunas, the Czechoslovakian chargé d'affaires Jan Skalicky noted that the Baltic states would consider the principles of their cooperation with regard to the proposal to join the Eastern Pact as well. When evaluating international circumstances, he noted that "Russia supports the alliance of the Baltic states because it sees it beneficial to itself. Poland works against it, while Germany will never agree to any cooperation among the Baltic states which it perceives as a move against it and the expansion of its interests to the East". ${ }^{14}$ France did not oppose to the formation of the Baltic Entente as well. As noted by M. Ilmjärv, "in the spring and summer of 1934 Paris viewed the Baltic League as a part of the Eastern Pact. On June 14, on the request of his government, the French envoy in Riga told Munters that France welcomed the conclusion of the regional agreements in Eastern Europe in the framework of the League of Nations statutes, which later would develop into a wider regional pact. This meant that the Baltic states should not join the Eastern Pact singly, but as a Baltic bloc". 15

Lithuania supported its adherence to the Eastern Pact directly and expressed such a position to the Soviets even before the official proposal. The Lithuanian foreign minister stressed to the USSR envoy Karski that "we support any Russian initiative in this direction"; however, Lithuania brought forward specific requirements as well: "we are concerned that no act is projected, which could prejudice our specific problem, i.e. the Vilnius case, and could make an impression that we are changing our position in respect of the Vilnius issue". ${ }^{16}$ Lithuania had a firm position regarding the Vilnius issue and according to the Lithuanian foreign minister Stasys Lozoraitis, "we cannot enter into any treaties establishing territorial status quo". ${ }^{17}$ In the meantime, Latvia and Estonia approached the situation from their position. On July 3, the Estonian foreign minister Seljamaa revealed the position of the Estonian Government regarding the Eastern Pact to Soviet diplomats: if Germany and Poland decline taking part in the pact, Estonia is not interested in it either, and anyway Estonia in its calculations intends to take also the views of Great Britain into consideration. ${ }^{18}$ Two days later Vilhelms Munters,

\footnotetext{
14 Czechoslovakia Charge d'Affaires in Kaunas Jan Skalický report of 10.07.1934 from Kaunas to the Ministry of Foreign Affaires of Czechoslovakia, AMZV.Pz-Kaunas. 1934. č.j.200-duv.

15 Magnus Ilmjärv, „Estonia, Latvia, Lithuania and the Eastern pact project,“ Acta Historica Tallinnensia 10 (2006): 76

16 A Pro memoria from S.Lozoraitis Lithuanian Minister of Foreign Affairs 30.06.1934, Lithuanian Central State Archive (hereafter LCVA). F.383.Ap.7.B.1557. L.486-487

17 A secret Pro memoria from Stasys Lozoraitis Lithuanian Minister of Foreign Affairs 14.07.1934, LCVA. F.383.Ap.7.B. 1587. L. 145

18 Ilmjärv, 75

44
} 
Secretary-General of the Latvian Foreign Ministry, informed Stefan Brodovski, the Soviet envoy in Riga, that the Eastern Pact without Germany's participation would constitute an anti-German league and therefore would be unacceptable to Latvia. ${ }^{19}$ Lithuania had to accept the position of Latvia and Estonia, which did not change over time.

The Baltic states expressed their agreement to the Eastern Pact Latvia and Estonia on 29 July, Lithuania on 3 August; the same was repeated by Estonian and Lithuanian foreign ministers Seljamaa and Lozoraitis on their visit to Moscow. It was stated in the meeting between Lozoraitis and Litvinov that "the pause is due to the failure of Poland and Germany to pronounce their opinion on this matter", even though it could be sensed that the position of the two countries "is virtually negative but they keep procrastinating the final answer". ${ }^{20}$ When Lozoraitis declared that "we will not participate in any case regarding the Vilnius issue", Litvinov's reaction was as follows: "the conclusion of the pact is impossible without Lithuania. Even as regards the Lithuanian-Polish dispute". ${ }^{21}$

With negotiations over the Eastern Pact in progress, the stand that Lithuania and Czechoslovakia took in their foreign policy, in respect of Poland and Germany in particular, became increasingly closer. The diplomats and foreign ministers of the two countries involved in more active cooperation. Lozoraitis was showing an active interest in the position of Prague in respect of the Eastern Pact. After hearing the favourable opinion of the Czechoslovakian envoy in respect of the Eastern Pact in June, Lozoraitis highlighted that "in respect of the Eastern Pact, Lithuania took up the position identical to that of Czechoslovakia, i.e. it is willing to support every action strengthening the idea of peace".22 Even though the positions in respect of the Eastern Pact coincided, the relations with Poland and Germany got complicated. In 1934 Poland was increasingly more active in bringing forward the issue of national minorities in Czechoslovakia; the LithuanianPolish dispute over Vilnius persisted. German nazi moods got more active in Lithuania and Czechoslovakia; Germany brought claims to both countries over the protection of rights of national minorities. Czechoslovakian diplomats did not conceal the noticeable tactical similarity: "today Poland has not still crystallised its relations with Czechoslovakia and Lithuania, and

\footnotetext{
19 Ibid.

20 A absolutely secret Pro memoria from S.Lozoraitis Lithuanian Minister of Foreign Affairs 22.08.1934, LCVA. F.383.Ap.7.B.1566.L.5

21 Ibid., L.6

${ }^{22}$ Czechoslovakia Charge d'Affaires in Kaunas Jan Skalický report of 27.06.1934 from Kaunas to the Ministry of Foreign Affaires of Czechoslovakia, AMZV.Pz-Kaunas. 1934. č.j. 189-duv.
} 
if we took a closer look at the tactics chosen by the Polish Foreign Ministry to solve the two issues, we would find a lot of analogies". ${ }^{23}$

In August the Czechoslovakian envoy informed from Warsaw that Poland considered Lithuania a huge obstacle in the way of the Eastern Pact: "Poland follows an opinion that it cannot sign a guarantee treaty with a state which does not have diplomatic relations with Poland and which is still living with hopes to retrieve a part of the Polish territory". ${ }^{24}$ To the best of his knowledge, Poland was even taking various measures in respect of this issue: "the Soviet legation witnesses Polish protests against Lithuania by referring to the fact that the Soviets are in no hurry to sign non-aggression treaties with the countries which have not entered into diplomatic relations with it and, finally, which have unresolved territorial issues with it, e.g. Romania".25 Czechoslovakian diplomats were unsettled by a slightly different position followed by Poland in respect of regional cooperation, e.g. it frequently did not consider the Little Entente a single bloc; it expressed a desire for Hungary and Bulgaria to adhere to the pact.

As soon as Poland and Germany expressed their position, a breakthrough in the negotiations began. On 7 July the German foreign minister Neurath declared that Germany would not join the pact. He pointed the fear of the imminent French-Soviet domination in Europe as the main reason. ${ }^{26}$ Poland did not openly criticise the pact but it was nevertheless disturbed by a possibility that it might be required to let the Red Army move across its territory and by the ongoing dispute with Lithuania and Czechoslovakia. ${ }^{27}$ Germany and Poland gave their negative answer to the participation in the Eastern Pact - the former on 11 September, the latter on 27 September. It destabilised the situation and undermined the plans of regional cooperation. There was more uncertainty and various speculations than common agreement and clarity of the situation.

After Poland and Germany expressed their position, Lithuania, as well as Czechoslovakia, continued to hold on to their opinion supporting the conclusion of the Eastern Pact; they supported the calls coming from Moscow diplomats to continue the negotiations over the Eastern Pact. Beneš tried to convince the Lithuanian envoy Turauskas that if Poland contributed to the Eastern Pact, the reservation clause in respect of Lithuania and

\footnotetext{
${ }^{23}$ Czechoslovakia envoy extraordinary and minister plenipotentiary in Warsaw report of 08.05.1934 from Warsaw to the Ministry of Foreign Affaires of Czechoslovakia, AMZV.PzVaršava. 1934. č.j. 4826

24 Ibid., 25.08.1934, Pz-Varšava. č.j.8415

25 Ibid., 25.08.1934, Pz-Varšava. č.j. 8415

26 Żerko, 127.

27 Ibid., 126.

46
} 
Czechoslovakia had to be anticipated: "practically speaking, it would mean that in the event of an attack, Czechoslovakia and Lithuania could not expect help from Poland and vice versa - in the event of an attack, Poland could not expect assistance from Lithuania and Czechoslovakia. ${ }^{28}$ Not only the minister Lozoraitis but also the Lithuanian Government supported this position. Smiling, Lozoraitis then told the Czechoslovakian envoy: "it does not mean that Poland may have free hands". ${ }^{29}$

German and Polish intrigues in respect of the Little Entente did not remain unnoticed in Lithuania. The minister Stasys Lozoraitis and Juozas Urbšys inquired of the Czechoslovakian chargé d'affaires Skalicky what position Czechs followed in respect of the German attempts to attract Yugoslavia to their side. Skalicky replied that "Germany will now seek a shake-up aggravating the Central European consolidation and will be scheming wherever it finds a favourable field for that". ${ }^{30}$ Whereas Lithuanian politicians remained the passive observers of the processes evolving in the Little Entente, Czechoslovakian diplomats were very active in expressing their reaction towards the changing balance of powers: "The Polish actions in Yugoslavia, likewise equivalent actions in Romania, cannot be seen as anything else but a desire to weaken the internal reciprocal relations within the Little Entente and to undermine the mutual relations among the member countries. ${ }^{31}$ The Czechoslovakian envoy in Warsaw warned that the aim behind such actions was to draw Yugoslavia and Romania away from France" and it was even "suspected that Poland and Germany shared the roles for pursuing similar actions in Yugoslavia and Romania in the fulfilment of this aim". 32

At the end of November the minister Beneš expressed his doubts in the policy pursued by Poland and believed that Poland would finally refuse to sign the Eastern Pact. He paid attention to the fact that Poland might start bringing its demands for Romania to be included among the signatories of the pact. It was also the time of Romanian negotiations with the Soviets and Beneš believed that Poland had certain calculations: "the Polish proposal for Romania to join the Eastern Pact is calculated in such a way that a reaction is evoked in Russian and Romanian societies and the road for the

\footnotetext{
${ }^{28}$ Czechoslovakia Charge d'Affaires in Kaunas Jan Skalický report of 30.10.1934 from Kaunas to the Ministry of Foreign Affaires of Czechoslovakia, AMZV.Pz-Kaunas. 1934. č.j. 284-duv.

29 Ibid., 29.11.1934, Pz-Kaunas. č.j.307-duv

30 Ibid., 30. 10.1934, Pz-Kaunas. č.j. 284-duv

31 Czechoslovakia envoy extraordinary and minister plenipotentiary in Warsaw report of 31.10.1934 from Warsaw to the Ministry of Foreign Affaires of Czechoslovakia, AMZV.PzVaršava. 1934. č.j. 10551

32 Ibid., 31.10.1934, Pz-Varšava. č.j. 10551
} 
governments is encumbered". ${ }^{33}$ The Lithuanian diplomacy did not receive information from Belgrade or Bucharest directly as it did not have its diplomats in these countries. It failed to express its position regarding the relations within the Little Entente but continued to consider the Little Entente an example of safeguarding regional stability.

While Europe was overwhelmed with the discussions on the Polish and German participation in the Eastern Pact in autumn 1934, the Baltic states succeeded in reaching a common agreement and the treaty establishing the Baltic Entente was signed in Geneva on 12 September 1934. The Baltic Entente involved in negotiations over the Eastern Pact as a bloc of countries, whereas the Little Entente was represented by Czechoslovakia alone, showing its exclusive amiability to Lithuania and treating the establishment of the Baltic Entente with favour. The Romanian politicians did not express their direct position regarding the establishment of the Baltic Entente. ${ }^{34}$ According to historian Luboš Švec, "the Baltic states were not the initiators of the negotiations; they were meant to play the role of an object". ${ }^{35}$ Hence, the diplomats of the Baltic states "sought to obtain the maximum possible information about the negotiations, not to lose contacts with the events and to maintain their balance among the great powers". 36

It was in its first conference in Tallinn on 30 November - 3 December 1934 that the Baltic Entente voted for the adherence to the Eastern Pact. The Czechoslovakian chargé d'affaires Skalicky noted that by declaring its allegiance to the League of Nations, the Baltic Entente joined other regional alliances like the Little Entente and the Balkan Pact, whereas a united position in favour of the Eastern Pact might be vital for all Baltic states. ${ }^{37}$ However, in reality, alarming differences emerged among the members of the Baltic Entente while the discussions on the Eastern Pact were still in progress. Munters, Secretary General of the Latvian Foreign Ministry, highlighted the necessity to maintain neutrality, though in principle he was

33 Lithuanian envoy extraordinary and minister plenipotentiary in Prague Edvardas Turauskas report of 29.11.1934 from Prague to the Ministry of Foreign Affaires of Lithuania, LCVA.F.648.Ap.1.B.13.L.46

${ }^{34}$ Nevertheless, in spring, when cooperation possibilities were discussed at the meeting of the diplomatic academy in Paris, the Romanian delegate V. Pella highlighted the necessity of close cooperation in the North by referring to the Little Entente as an example. Czechoslovakia Charge d'Affaires in Kaunas Jan Skalický report of 15. 04.1934 from Kaunas to the Ministry of Foreign Affaires of Czechoslovakia, AMZV.Pz-Kaunas. 1934. č.j. 110-duv

${ }^{35}$ Luboš Švec, Československo a pobaltské státy v letech 1918-1939. Vývoj politických a hospodářských vztahů Československa s Litvou, Lotyšskem a Estonskem v meziválečném období (Praha, 2001), 235 36 Ibid., 235

37 Czechoslovakia Charge d'Affaires in Kaunas Jan Skalický report of 14.12.1934 from Kaunas to the Ministry of Foreign Affaires of Czechoslovakia, AMZV.Pz-Kaunas. 1934. č.j. 330-duv 48 
prone to support the Eastern Pact with Germany and Poland in it. Estonia was even more critical in respect of the possibilities of safeguarding security in Europe with its foreign minister Seljamaa asserting that the three countries must pursue an independent foreign policy. Lozoraitis did not request for Poland's and Germany's adherence to the pact. 38

The initiators of the Eastern Pact were well aware of the diverging orientation of Lithuania, Latvia and Estonia. It was even before the conference in Tallinn that Litvinov expressed his confidence in the establishment of the Baltic Entente to the Lithuanian envoy Petras Klimas but he nevertheless doubted that Lithuania would succeed in neutralising the Latvian and Estonian Polonophilism and Germanophilism. ${ }^{39}$ Beneš, as well, addressed the diverging moods of the Baltic states for a number of times by highlighting that the Baltic states "do not have a single position in respect of the Eastern Pact", Latvia and Estonia had certain doubts as to giving permission to the Russian army to move across their territories, whereas Lithuania did not find it relevant. ${ }^{40}$ Beneš was worried that under such circumstances Poland would attempt to exert its influence on Latvians and Estonians. ${ }^{41}$

The single voice in respect of the Eastern Pact among the members of the Baltic Entente was continuously lacking. On 5 December 1934, the USSR and France signed a protocol on the resumption of negotiations and the commitment not to enter into any treaties which could interfere with concluding the Eastern Pact. Czechoslovakia adhered to the protocol several days later; Lithuanian diplomats encouraged the Lithuanian Government not to procrastinate as well. After receiving information from diplomatic sources that "Beneš is absolutely convinced that Germany and Poland will not adhere to the pact and the pact will not be put to life", the Lithuanian envoy in Paris Petras Klimas encouraged the Lithuanian Government to seek for allies among the members of the Little Entente and the Balkan countries

\footnotetext{
38 Магнус Ильмярв, Безмолвная капитуляция. Внешняя политика Эстонии, Латвии и Литвы между двумя войнами и утрата независимости (с середины 1920-х годов до аннексии $b$ 1940) (Москва , 2012 г.) 155.

39 A Pro memoria from Petras Klimas Lithuanian envoy extraordinary and minister plenipotentiary in Paris (the conversation with Soviet Foreign Minister Maxim Litvinov in Geneva) 21.11.1934, LCVA.F.648.Ap.1.B.26.L.165

40 Lithuanian envoy extraordinary and minister plenipotentiary in Prague Edvardas Turauskas report of 29.11.1934 from Prague to the Ministry of Foreign Affaires of Lithuania, LCVA.F.648.Ap.1.B.13.L.46

${ }^{41}$ Ibid., L.46
} 
but "be cautious with Latvians and Estonians". 42 It was believed that a new regional group of countries was about to emerge: "That formation which through Czechs would be linked with the Little Entente and the Balkans would become a great peace guarantee protecting Europe against any Germany's "friends"". ${ }^{43}$ Lithuania and Latvia agreed to adhere to the protocol, while Estonia refused to do it. ${ }^{44}$ The members of the Baltic Entente did not join the protocol.

In the beginning of 1935 the relations of Lithuania and Czechoslovakia with Poland and Germany did not witness any changes; the position of Poland and Germany in respect of the Eastern Pact did not change as well. In the beginning of February 1935 the USSR envoy in Prague Aleksandrovsky explained to the Lithuanian envoy Turauskas that Poland was expecting to direct the German territorial expansion towards Austria; from there Germans could march to Southern Russia and Bessarabia. According to him, it could explain why the Romanian-Polish alliance was destabilised at that time and why Nicolae Titulescu was so eagerly supporting the Eastern Pact. ${ }^{45}$ Hence, the conduct of Poland and Germany played a role in the further actions of the Baltic Entente and the Little Entente. In evaluating the Lithuanian foreign policy orientation, Skalicky noted: "today Poland is in the best relations with Germany which is at conflict with Lithuania, while Poland is in uncertain relations with Russia whose relations with Lithuania are getting increasingly closer" ${ }^{46}$

In fact, in the beginning of 1935 the international arena was full of various speculations about the expected changes in the primary idea of the Eastern Pact. Lithuania was worried that "the Baltic states could be eliminated from any creative process of the pact altogether" ${ }^{\prime 7}$ The Baltic states were unsettled by the fact that the USSR might start considering other regional combinations with no place for the Baltic states in them. The minister Stasys Lozoraitis also warned the USSR envoy Karski that if the Eastern Pact was doomed to failure and other combinations among the great

\footnotetext{
42 Lithuanian envoy extraordinary and minister plenipotentiary in Paris Petras Klimas report of 12.12.1934 from Paris to the Ministry of Foreign Affaires of Lithuania, LCVA.F. 383.Ap.7.B. 1610.L. 53-54

${ }^{43}$ Ibid., L.52

44 Ильмярв, 156-157.

45 Lithuanian envoy extraordinary and minister plenipotentiary in Prague Edvardas Turauskas report of 08. 02.1935 from Prague to the Ministry of Foreign Affaires of Lithuania, LCVA.F.648.Ap.1.B.14.L. 53

46 Czechoslovakia Charge d'Affaires in Kaunas Jan Skalický report of 15. 01.1935 from Kaunas to the Ministry of Foreign Affaires of Czechoslovakia, AMZV.Pz-Kaunas. 1935. č.j. 21-duv

47 A Pro memoria from Petras Klimas Lithuanian envoy extraordinary and minister plenipotentiary in Paris (from Geneva) 19.01.1935, LCVA.F.648.Ap.1.B.27.L. 32 50
} 
powers were considered, it should not be forgotten that "those combinations would not be complete if the Baltic states were forgotten". ${ }^{48}$ It should be noted that despite having no instructions, Karski reassured that even if the Eastern Pact was doomed to fail, other ways for safeguarding security would be sought, by adding that "Russians and the French should spare no effort in trying to convince Latvians and Estonians." 49

Struck by the growing uneasiness, Lithuanian diplomats shared these moods with Beneš as well. However, he failed to answer whether he preferred the possibility of the pact with Poland and Germany or without them. Beneš believed that Czechoslovakia would contribute to the alliance between the USSR and France if it was concluded and was convinced that the Baltic states would do the same. The situation being rather obscure, the Lithuanian envoy Turauskas proposed closer cooperation between the Little Entente and the Baltic Entente believing that it was "the right moment for establishing a closer contact" (by means of visits, meetings in Geneva). He believed that such cooperation "would help the medium and small countries to show solidarity on important issues". The Czechoslovakian foreign minister avoided a direct answer and explained that the cooperation should not "create an impression that it is targeted against Germany or Poland. What is more, Russians could also suspect that it is targeted against them... Therefore, such cooperation was only possible "en étroite colloboration avec la Russie". ${ }^{50}$ The Lithuanian diplomat agreed to the rather reserved position expressed by Beneš but both politicians were well aware that small and medium-sized states had to establish closer cooperation, in particular with regard to the interests of the great powers.

After the visit of the French foreign minister Laval to London on 1-3 February 1935, the possibility of various regional combinations in the absence of Germany and Poland was openly discussed. The Baltic states found it important to hear about their destiny in such a scheme. ${ }^{51}$ The Lithuanian envoy in Riga got an impression that Munters avoided to give the final answer and started considering whether the Eastern Pact would at

\footnotetext{
48 A Pro memoria from Stasys Lozoraitis Lithuanian Minister of Foreign Affairs 31.01.1935, LCVA. F.383.Ap.7.B.1731. L.200

49 Ibid., L.200

50 Lithuanian envoy extraordinary and minister plenipotentiary in Prague Edvardas Turauskas report of 25.01.1935 from Prague to the Ministry of Foreign Affaires of Lithuania, LCVA.F.648.Ap.1.B.14.L.25-26

51 A secret Pro memoria from Stasys Lozoraitis Lithuanian Minister of Foreign Affairs 19.02.1935, LCVA. F.383.Ap.7.B. 1770. L.23-24
} 
all make any sense without Poland and Germany. ${ }^{52}$ In the meantime, "Estonians consider such issues premature, threatening to their interests and incompatible with their traditional policy". 53 The position of the three members of the Baltic Entente diverged. The Lithuanian minister Lozoraitis was no longer convinced by Skalicky's considerations about how the negotiations would be continued and if the issue of security of Eastern Europe was not solved, it would not be solved in the West or even in the South. ${ }^{5}$ He was also increasingly more sceptical regarding Karski's reassurances that "Russians and the French are firmly determined to bring the action of the Eastern Pact to a successful end". 55

The envoys from the Baltic states delivered démarches in Paris and London - on 9 March in the former and on 13 March in the latter. An interest was expressed to participate in the Eastern Pact and attention was paid to the situation which could evolve if the Baltic states did not participate in the security system. The Latvian envoy was reassured in Paris that "the agreement concluded with Russians in Geneva is strictly followed and in the meantime there can be no question of any modifications whatsoever" ${ }^{\prime 56}$ While in Kaunas, Lozoraitis expressed in plain language when talking to Skalicky how important it was for the Lithuanian Government that Prague was well aware of the situation and that it supported Lithuania on the Eastern Pact. ${ }^{57}$ The Baltic states could sense that the negotiations over the Eastern Pact moved to the capitals of the great powers and they were no longer directly involved in them.

On 6 April the USSR asked the three Baltic states through diplomatic channels whether they would agree to participate in the pact without Poland and Germany participating in it. It was already a proposal of a new regional combination. After discussing the matters with Latvian and Estonian envoys

\footnotetext{
52 Lithuanian envoy extraordinary and minister plenipotentiary in Riga Juozas Urbšys report of 20.02.1935 from Riga to the Ministry of Foreign Affaires of Lithuania, LCVA.F. 383.Ap.7.B. 1494 a. L. 84

53 Lithuanian envoy extraordinary and minister plenipotentiary in Tallinn Bronius Dailidè secret report of 23.02.1935 from Tallinn to the Ministry of Foreign Affaires of Lithuania, LCVA.F.383.Ap.7.B. 1770. L.19

54 Czechoslovakia Charge d'Affaires in Kaunas Jan Skalický report of 14.02.1935 from Kaunas to the Ministry of Foreign Affaires of Czechoslovakia, AMZV.Pz-Kaunas. 1935. č.j. 65-duv

55 A Pro memoria from Stasys Lozoraitis Lithuanian Minister of Foreign Affairs 05.03.1935, LCVA. F.383.Ap.7.B.1731. L. 196

${ }^{56}$ Lithuanian envoy extraordinary and minister plenipotentiary in Paris Petras Klimas report of 09.03.1935 from Paris to the Ministry of Foreign Affaires of Lithuania, LCVA.F. 383.Ap.7.B. 1492 a. L. $41-42$

${ }^{57}$ Czechoslovakia Charge d'Affaires in Kaunas Jan Skalický report of 16. 03.1935 from Kaunas to the Ministry of Foreign Affaires of Czechoslovakia, AMZV.Pz-Kaunas. 1935. č.j. 90-duv 52
} 
in Kaunas, the Lithuanian president and the prime minister, Lozoraitis decided to give the answer after the Stresa Conference. ${ }^{58}$ On 10-11 April, Riga hosted a meeting of Baltic diplomats which considered the interests of all countries and decided to give their final answer after the conference of the Baltic Entente to be held in Kaunas in the beginning of May.59 When talking to Kraski, Lozoraitis noted: "we could not put any more pressure on our Baltic allies and thus postponed the issue by trying to avoid any possible split" ${ }^{60} \mathrm{He}$ once again highlighted that in order to make influence on Tallinn and Riga, Lithuanian steps were not sufficient; Russians and the French had to make them as well. ${ }^{61}$ In the meantime, Beneš, as indicated by subsequent events, accurately identified the USSR goals by warning Lithuanian diplomats that such an inquiry might only be a manoeuvre before the Stresa Conference. ${ }^{62}$ Beneš himself declared to the Lithuanian envoy that he would also support a six-party pact if a different agreement was not possible. ${ }^{63}$

In April the consideration on other possible regional blocs by the members of the Baltic Entente began. Lozoraitis even asked Karski whether such a combination would be possible if Lithuania was the only Baltic state joining it. ${ }^{64}$ A question was even brought up in Riga whether the Baltic states should not offer some new ideas for safeguarding security. Munters was prone to believe that the security of Eastern Europe could best be safeguarded by such a combination which would consist of the USSR, the Baltic states, Poland and Germany, whereas Czechoslovakia would be excluded as it does not share a common border with the USSR. If Czechoslovakia expressed its intention to participate, Hungary and Romania would then have to be included as well. ${ }^{65}$

In the meetings held in Geneva in the middle of May Litvinov was more preoccupied with the matters of the Little Entente and France. Litvinov

\footnotetext{
58 A Pro memoria from Stasys Lozoraitis Lithuanian Minister of Foreign Affairs, LCVA. F.383.Ap.7.B.1731.L.188-189

59 reikalu ministrai: 1918-1940 (Kaunas 1999), 301.

60 A Pro memoria from Stasys Lozoraitis Lithuanian Minister of Foreign Affairs 16.04.1935

(the conversation with Soviet Minister in Kaunas Mihail Karski), LCVA. F.383.Ap.7.B. 1673.L.17

61 Ibid., L.17

62 Lietuvos užsienio..., 302

63 Lithuanian envoy extraordinary and minister plenipotentiary in Prague Edvardas Turauskas report from Prague to the Ministry of Foreign Affaires of Lithuania, LCVA.F.648.Ap.1.B.14.L. 174

64 A Pro memoria from Stasys Lozoraitis Lithuanian Minister of Foreign Affairs 16.04.1935 (the conversation with Soviet Minister in Kaunas Mihail Karski), LCVA. F.383.Ap.7.B. 1673.L.17

65 A Pro memoria from Juozas Urbšys Lithuanian envoy extraordinary and minister plenipotentiary in Riga 15.04.1935, LCVA. F.383.Ap.7.B.1673. L.23-24.
} 
explained to Klimas that the abstention of the members of the Baltic Entente from giving the answer regarding the six-party pact and its forwarding to the conference in Kaunas showed that the Baltic states "were actually indifferent in this respect". The Soviets were not planning to bring up that question again and the Baltic states "chose that isolation by themselves". ${ }^{66}$ This time he said in plain language: "We will not make any more proposals because you are not concerned with your own interests... Finally, the French are not willing to give you any guarantees as well, they do not want to offer assistance and we have no reason to request what you yourself are avoiding...". ${ }^{67}$ When Klimas inquired why Russians cannot enter into such a treaty with the Baltic states which was anticipated to be concluded with Czechs, Litvinov reminded that France was not willing to help the Baltic states, the more so Lithuania. ${ }^{68}$ On his part, E. Beneš was calm and pronounced that "he would sign everything that the French and Russians agree upon" 69 and calmed Lithuanians by saying that if the French were not willing to give Lithuania any guarantees, especially as regards the German aggression, "no pessimistic conclusions should be drawn" from it. ${ }^{70}$ By reassuring that there was no actual threat to Lithuania from the side of Germany, Beneš tried to convince that "the task of peace is a long-lasting task and it will never end", whereas the unrealised Eastern Pact could be replaced with some other project. ${ }^{71}$

There, the French made it clear that, should Germany reject the Eastern pact, they intended to negotiate 'some agreement' with Soviet Russia.72 The resolution in the negotiations over the Eastern Pact became the signing of mutual assistance treaties between the USSR and France on 2 May 1935 and between the USSR and Czechoslovakia on 16 May 1935. Thus, Czechoslovakia, as a member of the Little Entente, achieved, at least for the time being, certain security commitments in its respect, whereas the members of the Baltic Entente were left behind. In fact, in the conference of the Baltic Entente held in Kaunas on 6-8 May the Little Entente was referred to as seeking to safeguard security in Europe, whereas the members of the

\footnotetext{
${ }^{66}$ Lithuanian envoy extraordinary and minister plenipotentiary in Paris Petras Klimas report of 15-19.04.1935 from Geneva to the Ministry of Foreign Affaires of Lithuania, LCVA.F. 648.Ap.1.B.27.L. 258

67 Ibid., L. 258

68 Ibid., L. 259

69 Ibid., L.265

70 Ibid., L.265

71 Ibid., L.265-266

72 Keith Neilson, Britain, Soviet Russia and the Collapse of the Versailles Order, 1919-1939 (New York 2006), 133.

54
} 
Baltic Entente undertook in the resolution of the conference to put every possible effort for safeguarding security and that the efforts made in the drafting of the Eastern Pact would be fruitful. ${ }^{73}$ Skalicky was prone to doubt whether the great powers were willing to strengthen the security of the Baltic Entente; they were most likely more willing to enhance their expansion in the region. ${ }^{74}$

The negotiations over the Eastern Pact brought the interests of the Baltic states closer to those of the Little Entente as all countries were concerned with safeguarding security. Poland and Germany were the key factor of insecurity. However, the progress of negotiations made it clear that each country was more concerned with its security than the common security of the entire bloc, even though both the Little Entente and the Baltic Entente were established for the sake of safeguarding security of their member states and harmonising their foreign policy in this respect. Both the Little Entente and the Baltic Entente declared their agreement to the Eastern Pact but the key difference was that the Baltic Entente was expected to participate in the Eastern Pact directly, whereas only Czechoslovakia was singled out from among the members of the Little Entente. Lithuania and Czechoslovakia were the two countries which were most actively concerned with the conclusion of the Eastern Pact and most eagerly supported the idea of regional integration. Romania supported the idea of the Eastern Pact; however, the process of negotiations did not bring it closer to the Baltic states; Lithuanian diplomats did not have any direct contacts with Romanians as well; they did not pay close attention to Romanian interests. Latvia was the only country which had a chance to hear out the Romanian position through its representation in Warsaw. In 1935 other possible ideas of regional integration involving the members of the Baltic Entente and the Little Entente were already discussed but an extensive range of interests prevented them from achieving broad regional integration in Europe.

\section{References:}

\section{A. Archives:}

Archive of Ministry of Foreign Affaires of Czech Republic (AMZV):

\footnotetext{
73 The resolution of the Second Baltic Entente Conference 08.05.1935 Kaunas. In: Zenonas Butkus, Česlovas Laurinavičius, eds. Baltijos valstybiu vienybès ideja ir praktika 1918-1940 metais (Vilnius, 2008), 557.

${ }^{74}$ Czechoslovakia Charge d'Affaires in Kaunas Jan Skalický report of 10.05.1935 from Kaunas to the Ministry of Foreign Affaires of Czechoslovakia, AMZV.Pz-Kaunas. 1935. č.j.158-duv
} 
- Pz-Kaunas. 1934. č.j. 110-duv, 189-duv, č.j.200-duv., č.j. 284-duv, č.j.307-duv, č.j. 330-duv

- Pz-Kaunas. 1935. č.j. 21-duv, č.j. 65-duv, č.j. 90-duv, 158-duv

- Pz-Varšava. 1934. č.j. 4826, Pz-Varšava. č.j.8415, č.j. 10551

Lithuanian Central State Archive (LCVA):

- F.383.Ap.7, B. 1492, B. 1494, B.1557, B.1566, B. 1587, B. 1610, B. 1673, B.1731, B. 1770

- F.648. Ap.1. B.13, B.14, B.26, B.27

B. Books and articles:

Butkus, Zenonas, Česlovas Laurinavičius, eds. Baltijos valstybiu vienybejs ideja ir praktika 1918-1940 metais. Vilnius, 2008.

Bystrický Valerián. Kolektíona bezpečnost' anebo neutralita: balkánske štáty a vytváranie záruk bezpečnosti v 30. rokoch. Bratislava, 1981.

Ilmjärv, Magnus. "Estonia, Latvia, Lithuania and the Eastern pact project." Acta Historica Tallinnensia 10 (2006).

Ильмярв, Магнус [Ilmjärv, Magnus]. Безмолвная капитуляциия. Внешняя политика Эстонии, Латвии и Литвы между двумя войнами и утрата независимости (с середины 1920-х годов до аннексии в 1940) [Silent submission: formation of foreign policy of Estonia, Latvia and Lithuania (period from mid-1920s to annexation in 1940)]. Москва , 2012.

Lietuvos užsienio reikalu ministrai: 1918-1940. Kaunas 1999.

Neilson, Keith. Britain, Soviet Russia and the Collapse of the Versailles Order, 1919-1939. New York 2006.

Sládek, Zdeněk. Malá dohoda 1919-1938. Praha, 2000.

Švec Luboš. Československo a pobaltské státy v letech 1918-1939. Vývoj politických a hospodářských vztahů Československa s Litvou, Lotyšskem a Estonskem v meziválečném období. Praha, 2001.

Wandycz Piotr. The twilight of France Eastern Alliances 1926-1936. Princeton, New Jersey, 1988.

Żerko, Stanisław. Niemiecka polityka zagraniczna 1933-1939. Poznań, 2005. 